\title{
KARAKTERISTIK DAN GENESA SAMPEL MINERAL DI DAERAH SAPAYA MENGGUNAKAN METODE MEGASKOPIS
}

\author{
Muh Resky Ariansyah*, Nur Ayu Anas, Novita Reskiyah Sari, Muh. Reza Pahlevi \\ Laboratorium Geofisika Padat, Departemen Geofisika, Universitas Hasanuddin, Makassar \\ *Penulis koresponden. Alamat email: reskyariansyah97@gmail.com
}

\begin{abstract}
Abstrak
Sapaya di Sulawesi Selatan merupakan satu dari sekian banyak daerah di Indonesia yang berpotensi terdapat berbagai macam mineral karena sejarahnya yang merupakan gunungapi purba. Penelitian ini bertujuan untuk mengidentifikasi mineral yang terkandung dalam beberapa sampel batuan dengan menganalisis sifat-sifat fisik dan melakukan tes reaksi kimia pada batuan. Metode penelitian yang digunakan adalah analisa batuan dan mineralogi. Hasil penelitian menunjukkan bahwa di daerah Sapaya terdapat jenis batuan tufa dengan jenis endapan primer, jenis batuan beku dengan mineral kuarsa $\left(\mathrm{SiO}_{2}\right)$ dan breksi yang mengandung karbonat sebagai bentuk alterasinya. Setelah mengetahui hasilnya, juga diprediksi proses dari pembentukan endapan mineral di Sapaya untuk lebih memahami kondisi mineral di Sapaya.
\end{abstract}

Kata Kunci: Sapaya, Genesa, Mineral.

\begin{abstract}
Sapaya in South Sulawesi is on from many area in Indonesia that has a potential to contains various kinds of mineral because of it's history as the ancient volcano. This study aims to identify mineral contain from rock samples by analyse physical properties and do chemical testing on the rocks. The method used in this study are rocks and mineralogy analysis. The results showed that Sapaya has a tufa rock with a type of primary mineral deposit, igneous rock with Quartz minerals $\left(\mathrm{SiO}_{2}\right)$ and breccia that contain carbonate as the alteration form. After knowing the result, also put a prediction of the process of mineral deposits forming in Sapaya to understand more about mineral condition in Sapaya.
\end{abstract}

Keywords: Sapaya, Genesis, Mineral.

\section{Pendahuluan}

Berdasarkan penelitian dari Irfan Syah dkk. (2015), dapat dilihat bahwa terlihat relief kasar berupa pegunungan dan perbukitan dari bentangalam Gunungapi Sapaya yang tersusun oleh breksi. Dari hasil pengamatan dapat disimpulkan bahwa Gunungapi Sapaya pernah mengalami erupsi hebat pada jaman dahulu berdasarkan lengkungan yang diduga merupakan kaldera.

Saat ini, bentuk bentangalam di Sapaya sudah tidak kerucut yang diperkirakan disebabkan oleh sebuah letusan besar yang selanjutnya terjadi erosi secara terus menerus di lokasi tersebut. Tetapi bentuk kerucutnya masih bisa dikenali apabila 
dilakukan rekonstruksi berdasarkan kemiringan dan kemenerusan dari lereng.

Terdapat sebuah sungai di area Sapaya yang dinamakan Sungai Jenelata. Secara geografis, daerah aliran Sungai Jenelata berada di $119^{\circ} 32^{\prime} 00^{\prime \prime} \mathrm{BT}$ - $119^{\circ} 50^{\prime} 00^{\prime}$ 'BT dan $05^{\circ} 15^{\prime} 00^{\prime \prime}$ LS - $05^{\circ} 27^{\prime} 00^{\prime \prime}$ LS. Dimana sungai Jenelata ini diperkirakaan merupakan aliran letusan dari Gunungapi Purba Sapaya.

Mineral-mineral yang terbentuk pada kondisi dan waktu tertentu yang berbeda dapat membentuk magma. Suhu atau pun temperatur yang berbeda dapat mempengaruhi proses pengkristalan suatu mineral. Berbagai macam batuan di alam memiliki jenisnya masing-masing, jenis batuan tersebut dapat ditentukan berdasarkan komposisi kimia serta karakteristik fisik yang dimilikinya berdasarkan kandungan mineral yang dikandungnya. Berdasarkan kondisi tersebut, melihat bahwa Sapaya adalah gunungapi purba yang pernah mengalami erupsi sehingga kemungkinan di daerah ini terdapat beberapa jenis mineral. Tujuan dari penelitian ini adalah untuk menganalisa jenis mineral dari beberapa sampel batuan yang diambil di daerah Sapaya dan memberikan analisis mengenai proses pembentukan mineralnya

\section{Metode Penelitian}

Sampel batuan dan mineral diambil dari beberapa titik untuk selanjutkan diidentifikasi jenis batuan dan mineralnya serta untuk mengetahui material yang menyusun batuan dan mineral tersebut.

Metode yang dilakukan untuk mengetahui sifat-sifat dari sampel batuan adalah analisis batuan dan mineralogi dengan identifikasi fisik dan tes reaksi kimia dari batuan, seperti menentukan warna segar dan warna lapuk dari batuan, jenis endapan, komposisi mineral, serta reaksi kimia yang terjadi pada batuan setelah ditetesi $\mathrm{HCl}$.

Langkah awal yang dilakukan adalah pengambilan sampel batuan dari lokasi penelitian, dalam hal ini, diambil 3 sampel berbeda di sekitar area Sapaya. Kemudian dilakukan identifikasi fisik batuan untuk mengetahui mineral yang terkandung di dalamnya. Selanjutnya dilakukan pengujian kimia pada batuan di laboratorium dengan meneteskan larutan $\mathrm{HCl}$ pada irisan batuan yang memperlihatkan mineral-mineral dari batuan untuk mengetahui kandungan karbonat dari mineral.

\section{Hasil dan Pembahasan}

Berdasarkan pengambilan data dan pengolahan sampel batuan pada daerah Sapaya, hasil yang didapat adalah sebagai berikut:

\section{Sampel 1}

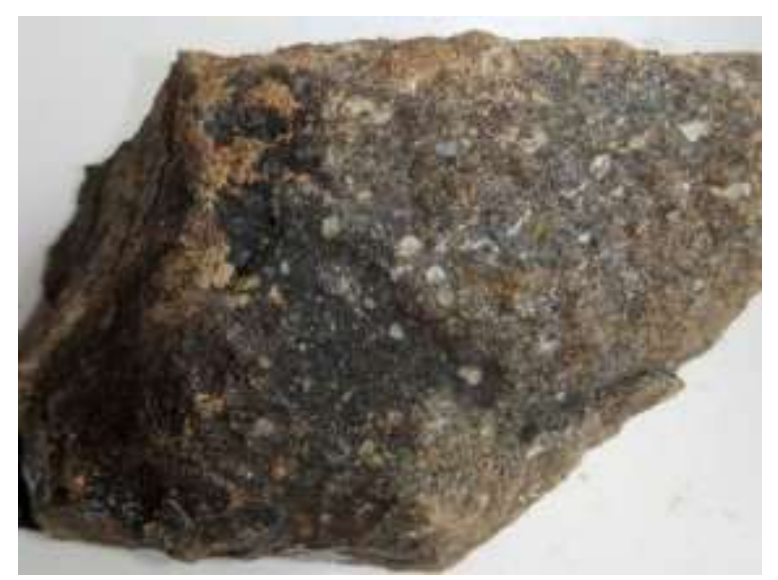

Gambar 1. Sampel 1 dengan jenis batuan tufa.

Pada sampel batuan dengan nomor sampel 1, dari pengamatan fisiknya dapat dilihat bahwa batuan memiliki warna segar yaitu putih serta warna lapuk yaitu abu-abu Kecoklatan. Dapat diintrepretasikan bahwa batuan ini merupakan jenis batuan pada wall rock yaitu batuan vulkanik. Ini disebabkan 
karena komposisi mineral yang mencakup mineral primer berupa mineral lempung dengan warna kuning yang bila ditetesi $\mathrm{HCl}$ tidak terjadinya reaksi. Mineral hasil mineralisasi adalah malasit dengan ciri berwarna hijau dimana mineral malasit ini merupakan hasil oksidasi tembaga sulfida dan diendapkan oleh air meteorik dalam bentuk diseminasi; kalkopirit yang ditandai dengan warna kuning keemasan; pirit yang ditandai dengan putih kekuningan berbentuk prismatic; dan galena dengan warna hitam kilap logam yang berbentuk diseminasi. Oleh karena itu, jenis endapan pada batuan ini yaitu late magmatic karena pada batuan ini hanya satu jenis mineral yaitu mineral hasil mineralisasi yang bersumber dari injeksi cairan sisa magma. Menurut hasil pendeskripsian ciri fisiknya, batuan ini merupakan batuan tufa lapili.

Komposisi mineral dari batuan ini yaitu terbagi dalam mineral primer berupa mineral lempung yang merupakan hasil erupsi vulkanik. Adapun mineral hasil mineralisasinya yaitu mineral malasit, lalkopirit, pirit dan galena.

\section{Sampel 2}

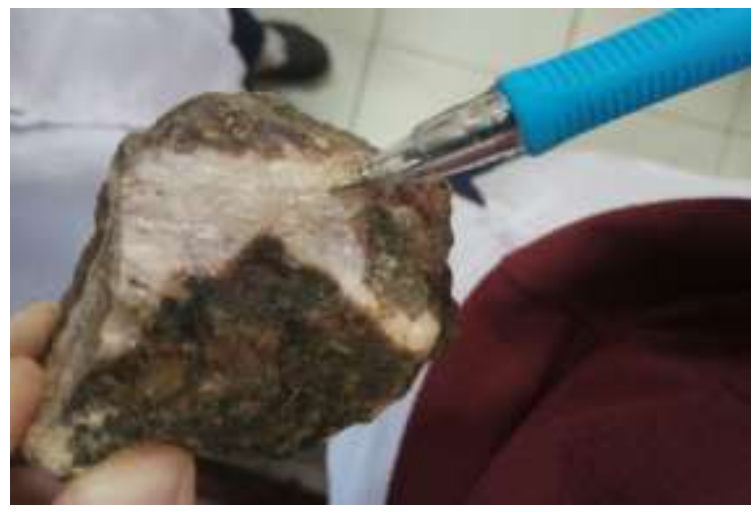

Gambar 2. Sampel 2 dengan jenis mineral berupa kuarsa.

Pada sampel batuan dengan nomor sampel 2 ini mempunyai ciri fisik yaitu berwarna segar putih serta warna lapuk yaitu abu-abu kecoklatan. Batuan ini memiliki jenis batuan pada wall rock yaitu batuan beku yang disebabkan karena komposisi mineral yang mencakup mineral primer berupa mineral kuarsa $\left(\mathrm{SiO}_{2}\right)$, biotit, piroksin, dan olivin dimana mineral kuarsa mempunyai ciri fisik dengan warna putih cerah yang bila ditetesi $\mathrm{HCl}$ tidak terjadi reaksi; mineral biotit dengan warna hitamnya dengan bentuk kubik dan mudah dihancurkan (brittle); mineral piroksin yang warnanya hitam dan lebih sulit dihancurkan jika dibandingkan biotit. Kemudian mineral altersinya berupa epidot dengan ciri berwarna hijau cerah dimana mineral epidot ini merupakan hasil ubahan dari mineral biotit, amphibol. Jenis endapan pada batuan ini yaitu hidrothermal atau alterasi karena pada batuan ini terdapat jenis mineral dari hasil alterasi atau mineral dari hasil larutan sisa.

\section{Sampel 3}

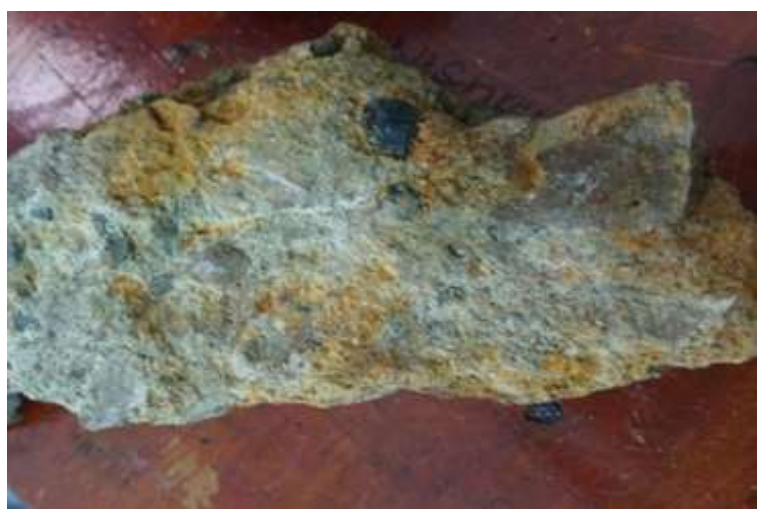

Gambar 3. Sampel 3 dengan jenis batuan berupa breksi.

Pada sampel batuan dengan nomor 3 berupa batuan breksi. Breksi merupakan istilah yang digunakan untuk mendeskripsikan batuan sedimen klastik yang berbentuk angular (sudut besar). Fragmen dari breksi berukuran lebih besar dari $2 \mathrm{~mm}$. Ruang kosong antar fragmen dapat diisi oleh semen yang merupakan mineral pengikat batuan maupun partikel kecil lainnya. Warna matrik, fragmen, serta semen dapat menjadi penentu warna dari batuan. Oleh sebab itu, 
breksi memiliki warna beragam tergantung partikel di dalamnya. batuan pertama (Tufa), terbentuk pada jenis endapan primer

Tabel 1 Klasifikasi sampel batuan di daerah Sapaya.

\begin{tabular}{|c|c|c|c|c|c|c|c|c|}
\hline \multirow[b]{2}{*}{ No } & \multirow[b]{2}{*}{$\begin{array}{l}\text { Nama } \\
\text { Sampel }\end{array}$} & \multirow[b]{2}{*}{$\begin{array}{l}\text { Warna } \\
\text { Segar }\end{array}$} & \multirow[b]{2}{*}{$\begin{array}{l}\text { Warna } \\
\text { Lapuk }\end{array}$} & \multirow{2}{*}{$\begin{array}{c}\text { Jenis } \\
\text { Endapan }\end{array}$} & \multicolumn{3}{|c|}{ Komposisi Mineral } & \multirow{2}{*}{$\begin{array}{c}\text { Reaksi } \\
\mathrm{HCl}\end{array}$} \\
\hline & & & & & $\begin{array}{c}\text { Mineral } \\
\text { Primer }\end{array}$ & $\begin{array}{l}\text { Mineral } \\
\text { Alterasi }\end{array}$ & Mineralisasi & \\
\hline 1 & Sampel 1 & Putih & $\begin{array}{l}\text { Abu-abu } \\
\text { Kecoklatan }\end{array}$ & Magmatik & Lempung & & $\begin{array}{l}\text { Kalkopirit, } \\
\text { Pirit, } \\
\text { Malasit, } \\
\text { Galena }\end{array}$ & Tidak \\
\hline 2 & Sampel 2 & Putih & $\begin{array}{l}\text { Abu-abu } \\
\text { Kecokletan }\end{array}$ & Hidrothermal & $\begin{array}{l}\text { Kuarsa, } \\
\text { Biotit, } \\
\text { Piroksen }\end{array}$ & Kalkopirit & Kuarsa & Tidak \\
\hline 3 & Sampel 3 & Putih & $\begin{array}{l}\text { Kuning } \\
\text { Keabu- } \\
\text { abuan }\end{array}$ & $\begin{array}{l}\text { Endapan } \\
\text { Sekunder }\end{array}$ & & & $\begin{array}{l}\text { Kuarsa, } \\
\text { Karbonat } \\
\text { klastik }\end{array}$ & Ya \\
\hline
\end{tabular}

Breksi memiliki ciri yaitu berbentuk tidak beraturan, hancuran batuan maupun mineral yang membentuk sudut fragmennya akan terlihat saling tertumpuk. Bagian bawah sebuah singkapan tempat puing-puing dari pelapukan mekanik berada merupakan lokasi dimana breksi biasa terbentuk. Hal inilah yang terjadi di Sungai Jenelata. Singkapan-singkapan yang ada mengalami pelapukan. Hasil dari pelapukan tersebut kemudian dibawa oleh aliran air ke sekitar singkapan dan mengendap disana.

Saat sampel batuan ditetesi $\mathrm{HCl}$, muncul reaksi berupa gelembung-gelembung. Hal ini menunjukan bahwa sampel batuan mengandung karbonat. Seperti pada kipas aluvial, beberapa breksi juga membentuk deposit yang dinamakan "debris flow". Fragmen yang angular dari breksi dapat diidentifikasikan bahwa mobilitas dari breksi tersebut hanya sedikit sehingga dia berapa dekat dari sumbernya.

Adapun klasifikasi dari sampel batuanbatuan di atas dijelaskan pada Tabel 1 .

\section{Kesimpulan}

Dari hasil pengamatan dari sampel batuan yang diperoleh di lapangan. Untuk sampel batuan pertama (tufa), terbentuk pada jenis endapan primer yaitu late magmatic karena bersumber dari injeksi cairan sisa magma. Pada sampel batuan kedua merupakan jenis batuan beku dengan komposisi mineral primer dan alterasinya berupa mineral kuarsa (SiO2). Pada sampel batuan ketiga berupa breksi. Batuan ini mengandung karbonat, hal ini terlihat ketika batuannya ditetesi dengan $\mathrm{HCl}$ terlihat reaksinya berupa gelembung-gelembung yang muncul pada batuan. Terbentuk pada jenis endapan sekunder (endapan placer) karena berasal dari pelapukan singkapan batuan kemudian terendapkan di sekitar singkapan tersebut.

\section{Daftar Pustaka}

Syah, I., Massinai, M.A., \& Syamsuddin. 2015. Pencitraan Bawah Permukaan Untuk Identifikasi Batuan Intrusi Menggunakan Metode Geolistrik. Skripsi, Universitas Hasanuddin. Diakses dari http://repository.unhas.ac.id/handle/1 23456789/14512. 